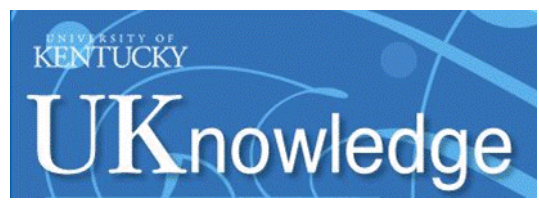

University of Kentucky

UKnowledge

\title{
Northeast-Oriented Transpression Structure in the Northern New Madrid Seismic Zone: Extension of a Shear Zone across the Reelfoot Fault Stepover Arm
}

\author{
Edward W. Woolery \\ University of Kentucky, ewoolery@uky.edu \\ Ali Almayahi \\ University of Kentucky
}

Follow this and additional works at: https://uknowledge.uky.edu/ees_facpub

Part of the Earth Sciences Commons, and the Environmental Sciences Commons

Right click to open a feedback form in a new tab to let us know how this document benefits you.

\section{Repository Citation}

Woolery, Edward W. and Almayahi, Ali, "Northeast-Oriented Transpression Structure in the Northern New Madrid Seismic Zone: Extension of a Shear Zone across the Reelfoot Fault Stepover Arm" (2014). Earth and Environmental Sciences Faculty Publications. 2.

https://uknowledge.uky.edu/ees_facpub/2

This Article is brought to you for free and open access by the Earth and Environmental Sciences at UKnowledge. It has been accepted for inclusion in Earth and Environmental Sciences Faculty Publications by an authorized administrator of UKnowledge. For more information, please contact UKnowledge@lsv.uky.edu. 
Northeast-Oriented Transpression Structure in the Northern New Madrid Seismic Zone: Extension of a Shear Zone across the Reelfoot Fault Stepover Arm

Digital Object Identifier (DOI)

http://dx.doi.org/10.1785/0120140066

Notes/Citation Information

Published in Bulletin of the Seismological Society of America, v. 104, no. 5, p. 2587-2596.

The copyright holders have granted the permission for posting the article here. 


\section{Bulletin of the Seismological Society of America}

This copy is for distribution only by

the authors of the article and their institutions in accordance with the Open Access Policy of the Seismological Society of America.

For more information see the publications section of the SSA website at www.seismosoc.org

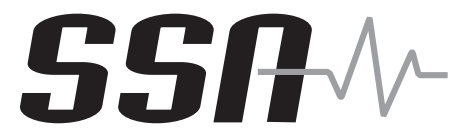

The Seismological Society of America 400 Evelyn Ave., Suite 201

Albany, CA 94706-1375

(510) 525-5474; FAX (510) 525-7204

www.seismosoc.org 


\title{
Short Note
}

\section{Northeast-Oriented Transpression Structure in the Northern New Madrid Seismic Zone: Extension of a Shear Zone across the Reelfoot Fault Stepover Arm}

\author{
by Edward W. Woolery and Ali Almayahi
}

\begin{abstract}
High-resolution seismic-reflection profiles recently acquired $12 \mathrm{~km}$ northeast of the New Madrid seismic zone's Reelfoot thrust and along the central axis of the Reelfoot rift, imaged steeply dipping $\mathrm{N} 30^{\circ} \mathrm{E}$ striking faults that have uplifted and arched post-Paleozoic sediments in a manner consistent with a dextral strike-slip component of displacement. The subparallel fault strands have been traced $1.4 \mathrm{~km}$ between reflection profiles. In order to evaluate the structure's potential regional scale, the strike was projected northeast $22 \mathrm{~km}$ to its intersection with a nearby industry profile. At the intersection, this lower-resolution profile exhibits a discrete $0.75 \mathrm{~km}$ wide structure with style and offset similar to the high-resolution lines. The high-resolution images indicate the deformation extends above Paleozoic bedrock, affecting the Late Cretaceous and Eocene Mississippi embayment sediments, as well as the base of the Quaternary. The Paleozoic and Cretaceous horizons show as much as 75 and $50 \mathrm{~m}$ of relief, respectively, with the middle Eocene and basal Quaternary disrupted 25 and $15 \mathrm{~m}$, respectively. Geologic and geophysical logs from a borehole adjacent to the seismic lines constrain the depth, velocity, and stratigraphic interpretations. We interpret the faults as a minimum $34 \mathrm{~km}$ northeast extension of the Axial fault zone from a throughgoing intersection with the left-stepover Reelfoot thrust.
\end{abstract}

\section{Introduction}

The New Madrid seismic zone (NMSZ) is an intraplate area of high seismic energy release. Along with the sequence of large earthquakes that occurred during the winter of 18111812 and similar clustered events found in the paleoseismic record, the NMSZ is the major contributor to the seismic hazard for much of the central United States (Johnston and Schweig, 1996; Tuttle et al., 2002) (Fig. 1). Most of the contemporary seismicity lies within the early Paleozoic Reelfoot rift system and beneath the Late Cretaceous and early Tertiary Mississippi embayment, an elongate southwest-plunging sediment-filled re-entrant basin (Cox and Van Arsdale, 2002; Csontos and Van Arsdale, 2008). Although the NMSZ is certainly more complex than a simple three-fault model, focal solutions allow it to be generalized as two northeast-oriented dextral strike-slip fault zone segments offset by a central northwest-oriented left-stepping restraining-bend thrust; however, its driving mechanism(s) remains relatively equivocal (Chiu et al., 1992; Johnston and Schweig, 1996; Pratt, 2012). In addition, ambiguity associated with slip rate, total displacement, strain accommodation, and location of related deformation is problematic for regional seismic-hazard evaluations. This has hindered a broad-based scientific consensus of the hazard and generated a significant amount of study and debate (e.g., Pratt, 1994, 2012; Schweig and Ellis, 1994; Newman et al., 1999; Cox et al., 2000; Van Arsdale, 2000; Tuttle et al., 2002; Calais et al., 2005, 2010; Smalley et al., 2005; Calais and Stein, 2009; Pratt et al., 2012; Pryne et al., 2013). The physical evidence needed for better defining the spatial and temporal seismotectonic characteristics as well as improving the associated seismic-hazard estimation models is complicated by the sparse surface deformation and poor preservation of tectonic-based geomorphic signatures; several mechanisms, however, are suggested to explain this: young seismicity, migrating seismicity, active Mississippi River fluvial dynamics, and broadly distributed strike-slip faulting (Pratt, 1994, 2012; Schweig and Ellis, 1994; Newman et al., 1999; Stein and Newman, 2004). Using reprocessed industry and recently acquired high-resolution seismic-reflection data, Pratt et al. (2012) interpreted several faults that displace shallow Quaternary sediment. Their fault interpretations were located in and outside the 


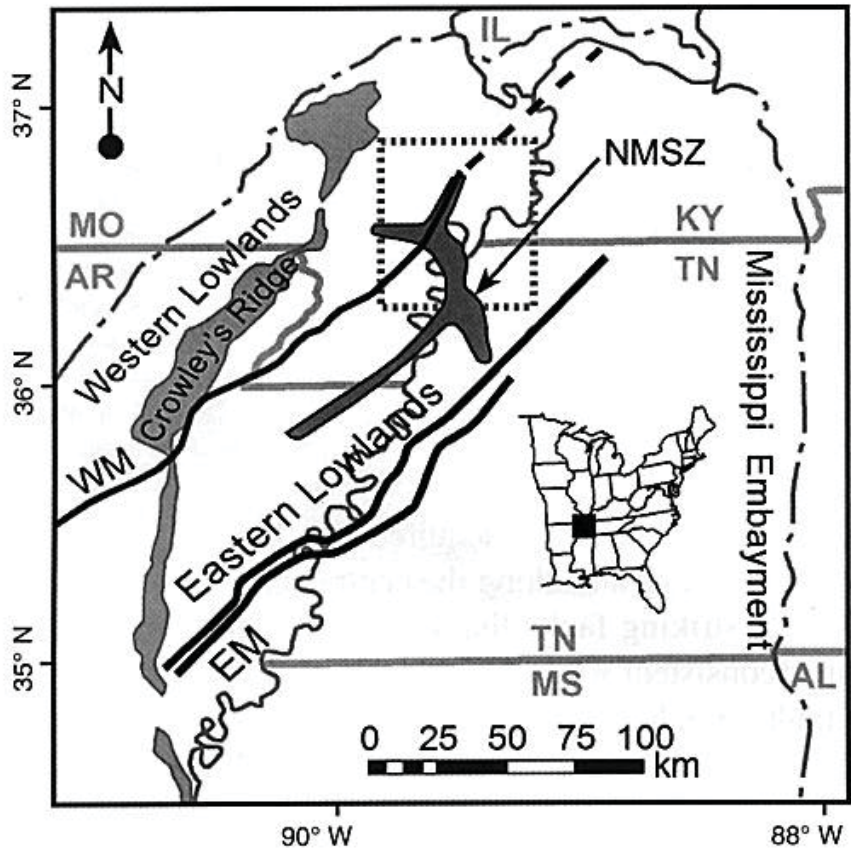

Figure 1. The NMSZ (dark-gray shaded area) is located primarily inside the Reelfoot rift (heavy black lines) (modified from Csontos et al., 2008). The structural tectonic features of the Reelfoot rift area are overlain by the Mississippi embayment sediments. The seismicity's southern arm is coincident with the Axial fault, and the central left stepover arm of seismicity is coincident with the Reelfoot fault. The gray dashed box defines the boundaries of Figure 2 .

margins of the NMSZ's southern seismicity arm Axial fault. They further observed that most faults exhibit strike-slip displacement characteristics, possibly indicative of a broad migratory shearing across the embayment. Odum et al. (2010) speculated, and more recently Pratt et al. (2012) further demonstrated, that the previously recognized bend in the NMSZ central stepover where it crosses the southern arm can be explained with the southern arm acting as a throughgoing dextral shearzone(Fig. 2). Between 10 and $12.5 \mathrm{~km}$ of strike-slip offset on the central arm's Reelfoot fault (Pujol et al., 1997; Csontos and Van Arsdale, 2008; Csontos et al., 2008), and approximately $5.5 \mathrm{~km}$ of horizontal displacement along its surface expression (Reelfoot scarp), were estimated (Pratt et al., 2012). This suggests a significant amount of accommodation prior to the Holocene was not transferred to the central stepover thrust fault but more likely continued to the northeast as strike slip, and that a component of throughgoing northeast accommodation may continue. Although Light Detection and Ranging surveys may eventually reveal surface deformation, substantiated seismotectonic topographic evidence for a northeast-extended shear zone is presently undefined northeast of the NMSZ's central stepover, an area that exhibits a much more diffuse seismicity pattern than its southern and central arms (Wheeler, 1997; Pryne et al., 2013).

We evaluate northeast-oriented fault strands that were recently discovered during a seismic-reflection investigation located approximately $12 \mathrm{~km}$ northeast of the Reelfoot scarp

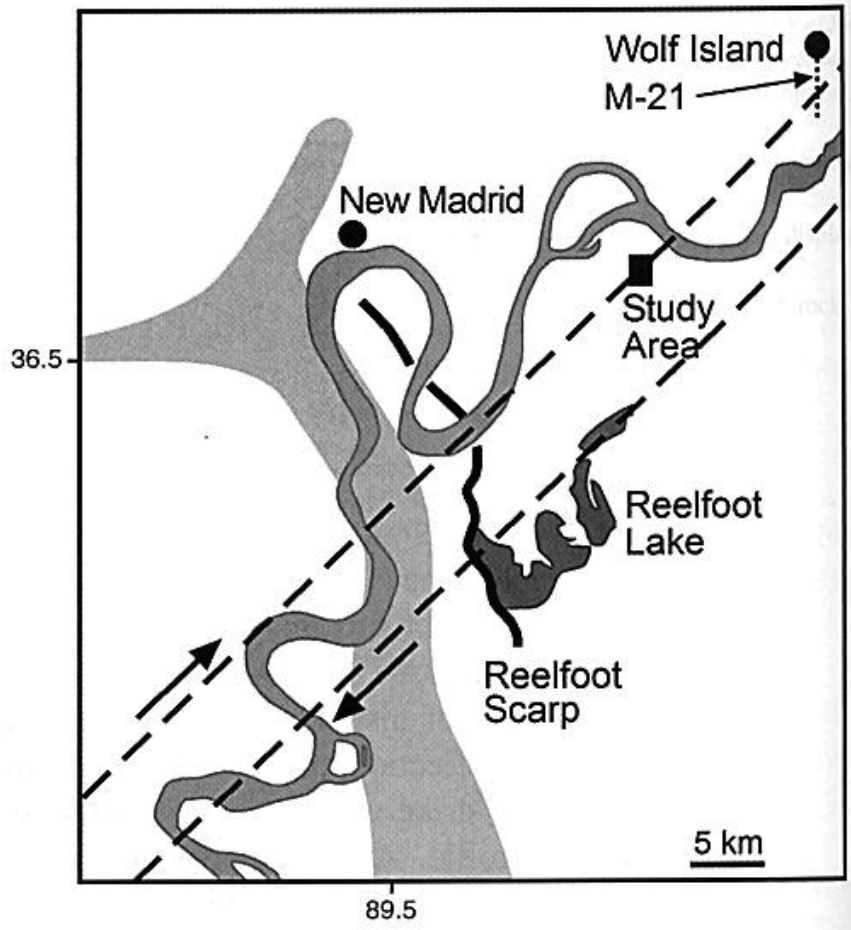

Figure 2. Northeast-striking shear zone representing the southem Axial fault and its projection (dashed lines) across the Reelfoot fault stepover as generally defined by the northwest-oriented contemporary seismicity (light gray area) (Pratt et al., 2012). Pujol et al. (1997) and Csontos and Van Arsdale (2008) among others interpret the bend in the seismicity pattern near the intersection of the stepover with the Axial fault as between 10 and $12.5 \mathrm{~km}$ of right-lateral offset along the Reelfoot fault. Pratt et al. (2012) report $\sim 5.5 \mathrm{~km}$ of lateral surface displacement along the Reelfoot scarp (black solid line). This significant difference in the subsurface and surface displacement estimates suggests a northeast continuation of the shear zone. Our highresolution seismic reflection lines were collected in an area (black rectangle) surrounding a vertical seismic observatory $12 \mathrm{~km}$ northeast of the Reelfoot scarp and along the western edge of the projected Axial fault. A section from a lower-resolution industry seismic line, M-21 (dotted line), also crosses the western edge of the projection and was used for regional correlation. M-21 is located $22 \mathrm{~km}$ northeast of the high-resolution data near the community of Wolf Island, Missouri (figure modified from Pratt et al., 2012).

in the context of a hypothesized northeast extension of the southern Axial shear zone through the central stepover thrust fault (Odum et al., 2010; Pratt et al., 2012). Our dataset includes four high-resolution $P$-wave seismic-reflection surveys totaling nearly $4.5 \mathrm{~km}$ that were collected in a $1 \mathrm{~km}$ radius of the central United States seismic observatory (CUSSO). CUSSO is a vertical borehole array of accelerometers and broadband seismometers located in a small rural community situated atop a subtle topographic high $(\sim 3 \mathrm{~m})$, called Sassafras ridge, within the Mississippi River floodplain of westernmost Kentucky (Fig. 3). The observatory's borehole penetrated the $585 \mathrm{~m}$ of embayment sediments and terminated approximately $8 \mathrm{~m}$ below the top of Paleozoic bedrock (Fig. 4). These borehole data allowed us to correlate five relatively coherent and continuous reflectors on the high-resolution profiles with the following stratigraphic 


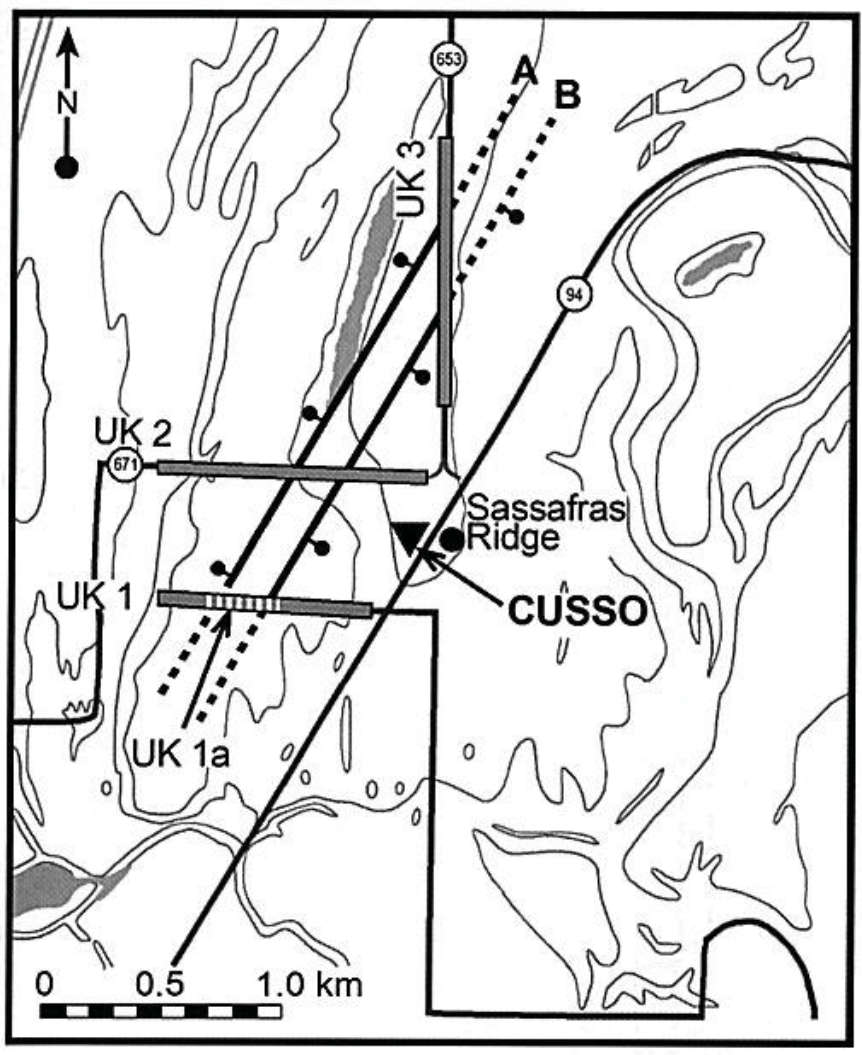

Figure 3. The seismic-reflection profiles are located in a small rural community, called Sassafras Ridge (black-filled circle), Kentucky, which sits atop a subtle topographic rise within the Mississippi River floodplain. The seismic lines were collected in a $1 \mathrm{~km}$ radius of the central United States seismic observatory (CUSSO) borehole (black-filled triangle) that penetrated $585 \mathrm{~m}$ of Quaternary, Tertiary, and Late Cretaceous (K) sediments and terminated in the underlying Paleozoic $(\mathrm{Pz})$ bedrock. Lines UK 1, 2, and 3 (heavy gray lines) imaged the deeper $\mathrm{K}$ and $\mathrm{Pz}$ horizons. Line UK $1 \mathrm{a}$ (white dashed line) was collected coincident with part of UK 1 but designed to image the shallower Tertiary and basal Quaternary sediments. The heavy black lines, labeled A and B, approximate the boundaries of an imaged pop-up horst feature that was correlated between the seismic lines. The labels are indexed to the fault interpretations on UK 1,2, and 3. Highways are dark gray lines with their identifying number circled.

units (Hunter, 2011): top of Paleozoic bedrock (Pz), top of Late Cretaceous Clayton-McNairy formation (K), top of Paleocene Porters Creek Clay (Tp), Eocene member of the Wilcox formation (Tw), and top of Eocene Jackson formation ( $\mathrm{Tj})$. Above the Jackson formation are Quaternary (Q) alluvial sands and gravels. The CUSSO borehole cuttings log along with downhole electrical and sonic velocity surveys provide constraint for the stratigraphic and depth-migrated seismic-reflection interpretations (Figs. 4, 5, 6, and 7).

\section{Seismic-Reflection Data and Interpretation}

The seismic-reflection data consist of four recently acquired high-resolution profiles (this study) and reinterpretation of a part of an older lower-resolution industry profile.
We collected east-west-oriented (lines UK 1, 1a, and 2) and north-south-oriented (UK 3) seismic-reflection profiles along rural roads in a $1 \mathrm{~km}$ radius of the CUSSO site (Fig. 3 ). These 12-fold data were recorded with a 24-bit engineering seismograph using $P$-wave energy generated from a $4 \mathrm{~kg}$ hammer and $15 \mathrm{~cm} \times 15 \mathrm{~cm}$ hardened aluminum plate. Five vertical hammer strikes were stacked at each shot point. In addition, two different receiver array geometries were used to optimally image both the relatively deep and shallow target stratigraphy. Specifically, a $10 \mathrm{~m}$ group/shot interval and $100 \mathrm{~m}$ near-offset source were used in lines UK 1,2 , and 3 to optimally image reflections from the tops of the deeper Cretaceous $(\mathrm{K})$ and Paleozoic bedrock $(\mathrm{Pz})$ stratigraphic horizons (Figs. 4 and 5); however, a reduced $2 \mathrm{~m}$ array interval and $50 \mathrm{~m}$ near-offset source were used for UK 1a. The smaller array dimension for the latter profile produced better reflected images for the Tertiary and base of the Quaternary stratigraphic horizons.

A conventional processing procedure was applied to all profiles and included band-pass filters, gain correction, residual statics, coherent noise mutes, and iterative velocity analysis. Frequency-wavenumber filtering, adaptive subtraction, frequency-offset deconvolution, and poststack Kirchhoff depth migration were also applied. The signal exhibited an average $50 \mathrm{~Hz}$ dominant frequency and $1900 \mathrm{~m} / \mathrm{s}$ velocity. This yielded vertical and detectable resolution of approximately 9.5 and $4.5 \mathrm{~m}$, respectively.

The stacked high-resolution reflection profiles are too closely spaced to confidently extrapolate the local geologic results to a meaningful regional scale, however. To provide better regional context for the high-resolution data interpretations, we also incorporate and evaluate a $6 \mathrm{~km}$ segment of a north-south-oriented $48 \mathrm{~km}$ long industry seismic line, Dow Chemical M-21, located approximately $22 \mathrm{~km}$ northeast of the CUSSO site (Fig. 2) (Howe, 1985). The 48-fold M-21 data were collected with vibratory energy sources and a $67 \mathrm{~m}(220 \mathrm{ft})$ shot/group interval; however, this array aperture and other associated acquisition parameters were not optimal for imaging the near-surface stratigraphy. The useful reflecting signals are limited to the K-T and $\mathrm{K}-\mathrm{Pz}$ stratigraphic horizons and deeper. In addition, the data are significantly lower resolution than the CUSSO seismic data. The dominant signal frequency for M-21 is approximately $25 \mathrm{~Hz}$, yielding a vertical and detectable resolution of 19 and $10 \mathrm{~m}$, respectively. These relatively long-wavelength signals often make separating the two primary reflectors difficult in some areas of the longer profile, as the end of the $\mathrm{K}$ reflection can interfere with the onset of the $\mathrm{Pz}$ reflection; however, this was not problematic in our section of interest, thus providing a usable temporal separation.

\section{Lines UK 1 and 1a}

Line UK 1 is a $650 \mathrm{~m}$ east-west-oriented profile collected along a level road $0.25 \mathrm{~km}$ south of CUSSO (Figs. 3 and 6). The two most prominent reflections are from the tops 


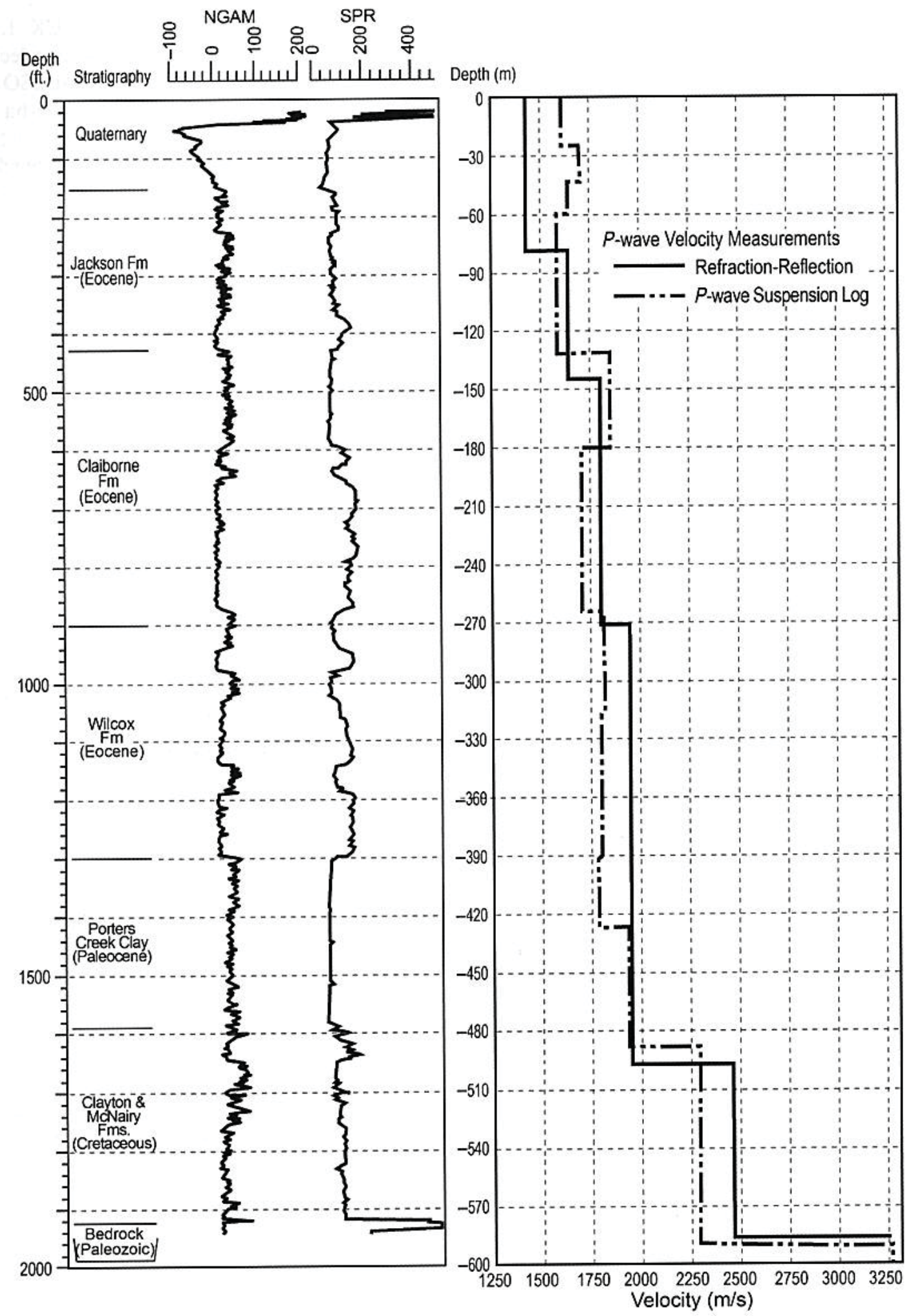

Figure 4. The stratigraphic and geophysical well-log interpretations from the CUSSO borehole are shown on the left side of the figure. In addition to the self-potential resistivity (SPR) and natural gamma (NGAM), borehole velocity measurements were made. The results from the $P$-wave suspension log are compared with the averaged reflection stacking velocities at the site (plotted on the right side of the figure). The surface elevation at the well is $91 \mathrm{~m}$.

of the $\mathrm{K}$ and $\mathrm{Pz}$ stratigraphic horizons; their resultant seismic migration depths agree with borehole data. Figure 6 shows the uninterpreted and interpreted seismic-reflection profiles.
Although the reflections above the $\mathrm{K}$ horizon have weaker and more discontinuous characteristics, the Porters Creek Clay and Wilcox formations are relatively coherent across 

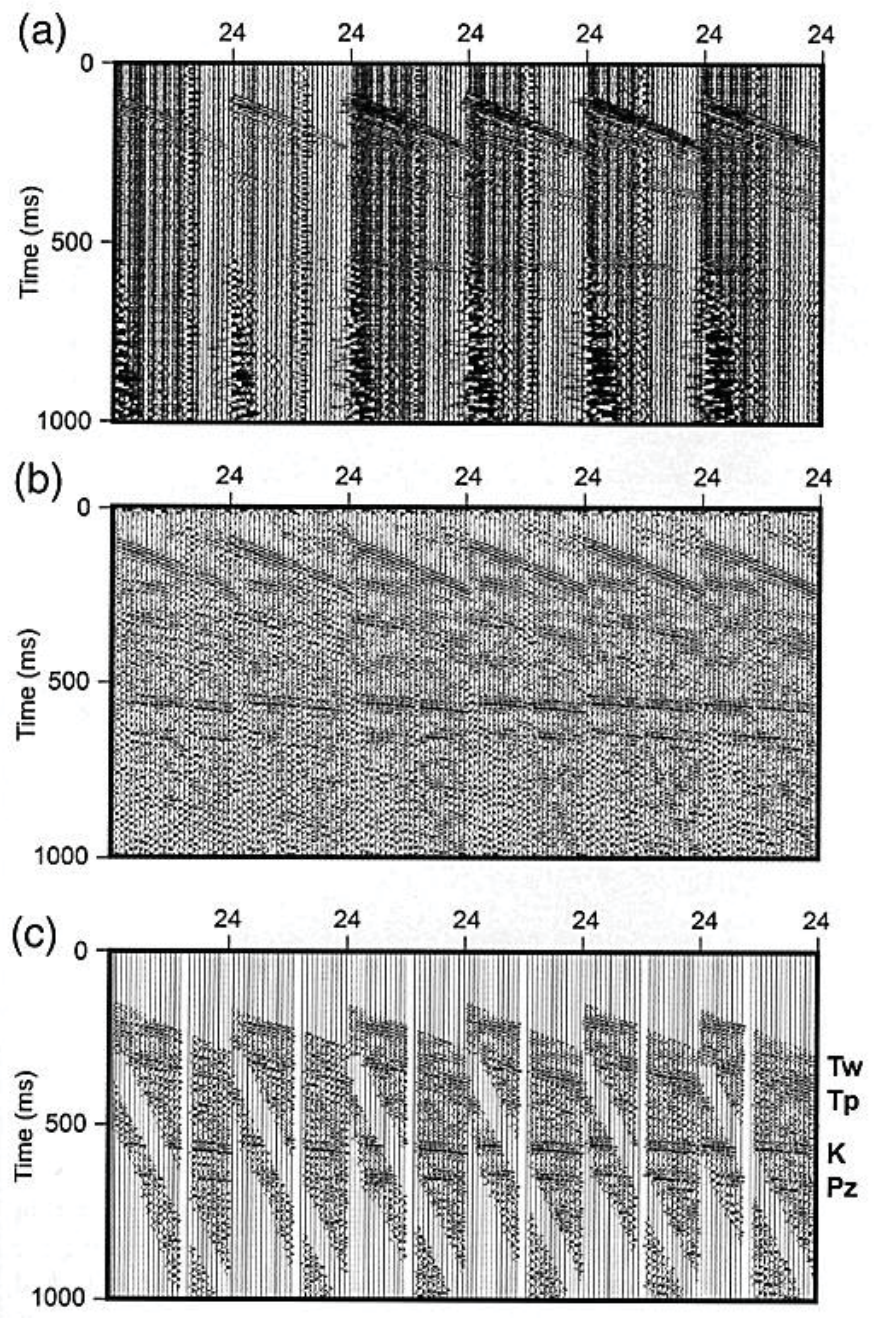

Figure 5. Six consecutive example 24-trace field file panels from UK 1 are shown. The $10 \mathrm{~m}$ spaced source and receiver arrays were used to optimally image the $\mathrm{K}$ and $\mathrm{Pz}$ horizons. The field files are shown in their (a) raw, (b) band-pass filtered/trace balanced, and (c) muted forms.

the profile. These stratigraphic interpretations also correlate with the adjacent borehole information. Structurally, we interpret a near-vertical fault that crosses the monoclinal flexure of the $\mathrm{K}$ and $\mathrm{Pz}$ reflectors near UK 1's trace number 80 , labeled $\mathrm{A}$ in the lower part of Figure $6 \mathrm{c}$. The fault affects the overlying horizons, including the Wilcox and younger strata. Vertical relief across this structure is approximately 50 and $75 \mathrm{~m}$ on the $\mathrm{K}$ and $\mathrm{Pz}$ horizons, respectively. A smaller fault is interpreted near trace 55, labeled B in the lower part of Figure $6 \mathrm{c}$. This feature has an estimated eastern downthrow of approximately $30 \mathrm{~m}$ for both the $\mathrm{K}$ and $\mathrm{Pz}$ horizons. As a composite, the shallower uplifted reflectors between faults A and $\mathrm{B}$ are arched and define a narrow, upward splaying, asymmetric pop-up or horst structure. We also interpret a fault at trace 100, shown as a dashed line and labeled C in the lower part of Figure $6 \mathrm{c}$, based on the abrupt change in the dip of the reflections, as well as a small reversed displacement. The fault $\mathrm{C}$ deformation in this profile is very subtle across the $\mathrm{K}$ and $\mathrm{Pz}$ horizons. The fault would not be suggested if not for the dip changes in the shallower reflections and the projection of a fault to this approximate station in the more definitive structural observations made in the other profiles. It is also possible that the primary deformation associated with the deeper part of fault $\mathrm{C}$ is located off the western end of UK 1 . Without additional data acquisition, the geologic reliability of the fault $\mathrm{C}$ interpretation is unknown.

Line UK 1a was acquired coincident with a part of UK 1 and across its interpreted structure (Fig. 3). The $330 \mathrm{~m}$ image, shown in Figure $6 \mathrm{~b}$ and the upper part of Figure $6 \mathrm{c}$, was arrayed to better image the Tertiary and basal Quaternary horizons. The stacked dataset is rich in reflected signal; however, the two most prominent and continuous are the tops of the Wilcox and Jackson formations. The primary faults, A and $\mathrm{B}$, imaged in UK 1 are also exhibited at the coincident UK 1a stations. The imaged faults appear to cross the Jackson formation, displacing the base of the Quaternary. The tops of the Wilcox and Jackson horizons have as much as 25 and $15 \mathrm{~m}$ of vertical relief, respectively. The nearsurface structural characteristics also show arched reflectors bounded by two primary near-vertical faults, A and B, that diverge upward similar to that imaged in UK 1 . The structure exhibited in the more detailed UK 1a image has characteristics consistent with a strike-slip induced pop-up or flower structure. UK 1a also shows the extension of fault $\mathrm{C}$ into the near-surface sediment. The abrupt change in dip and reversed displacement is more clearly resolved in this image than in UK 1.

\section{Line UK 2}

Line UK 2 is an $800 \mathrm{~m}$ long east-west-oriented profile (Fig. 7) collected $0.20 \mathrm{~km}$ north of CUSSO (Fig. 3). This profile was arrayed to image the deeper $\mathrm{K}$ and $\mathrm{Pz}$ target horizons. The reflections above the $\mathrm{K}$ horizon are more discontinuous than the $\mathrm{K}$ or $\mathrm{Pz}$; however, the reflections from the tops of the Porters Creek and Wilcox formations appear relatively coherent across the profile and correlate with the interpreted borehole stratigraphy. Two near-vertical faults are interpreted near trace numbers 90 and 45 based on the antiformal warping of the $\mathrm{K}$ and $\mathrm{Pz}$ horizons, as well as vertical elevation differences and abrupt dip changes on either side of fault traces. These faults are labeled A and B, respectively. The composite structure is interpreted as the same pop-up feature imaged along lines UK 1 and $1 \mathrm{a}$. The $\mathrm{K}$ and $\mathrm{Pz}$ appear to have nearly 45 and $70 \mathrm{~m}$ of offset, respectively, somewhat less than that estimated on UK 1 ; however, similar to UK 1, the largest vertical relief appears on the western side of the structure (i.e., fault A). A third near-vertical fault, labeled $\mathrm{C}$, is interpreted at trace 125 ; but it has less offset $(\sim 30 \mathrm{~m})$ and an opposite throw (westside up) as fault $\mathrm{A}$. Nonetheless, the measured fault $\mathrm{C}$ vertical offset in this line is more than that observed in UK 1. All faults appear to deform the Tertiary horizons. 
(a)

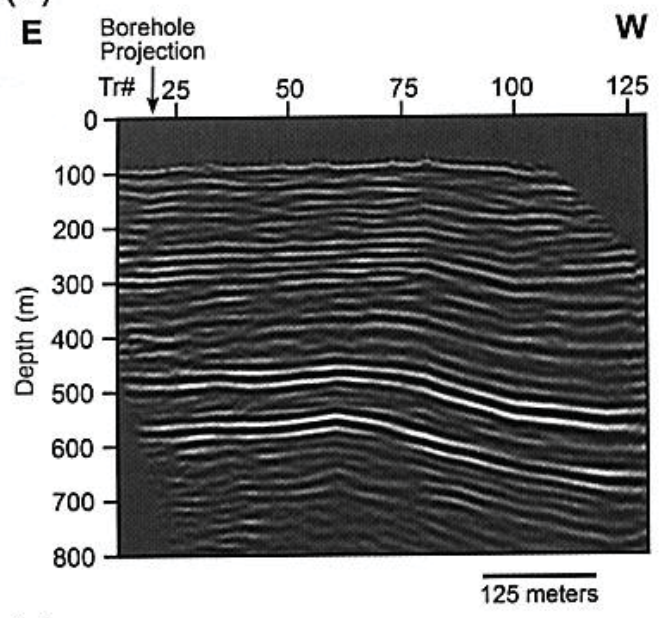

(b)

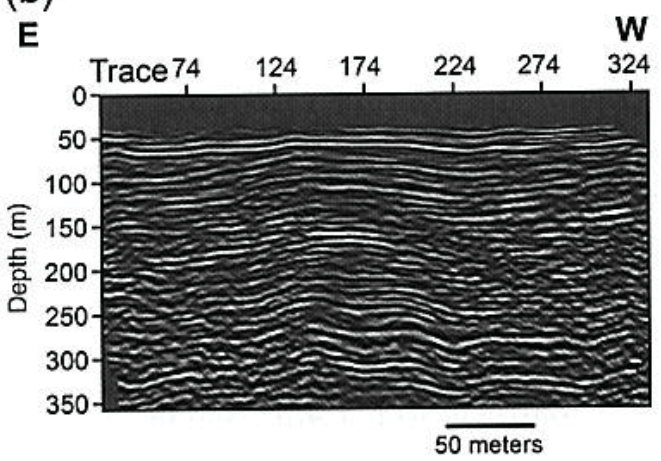

(c)

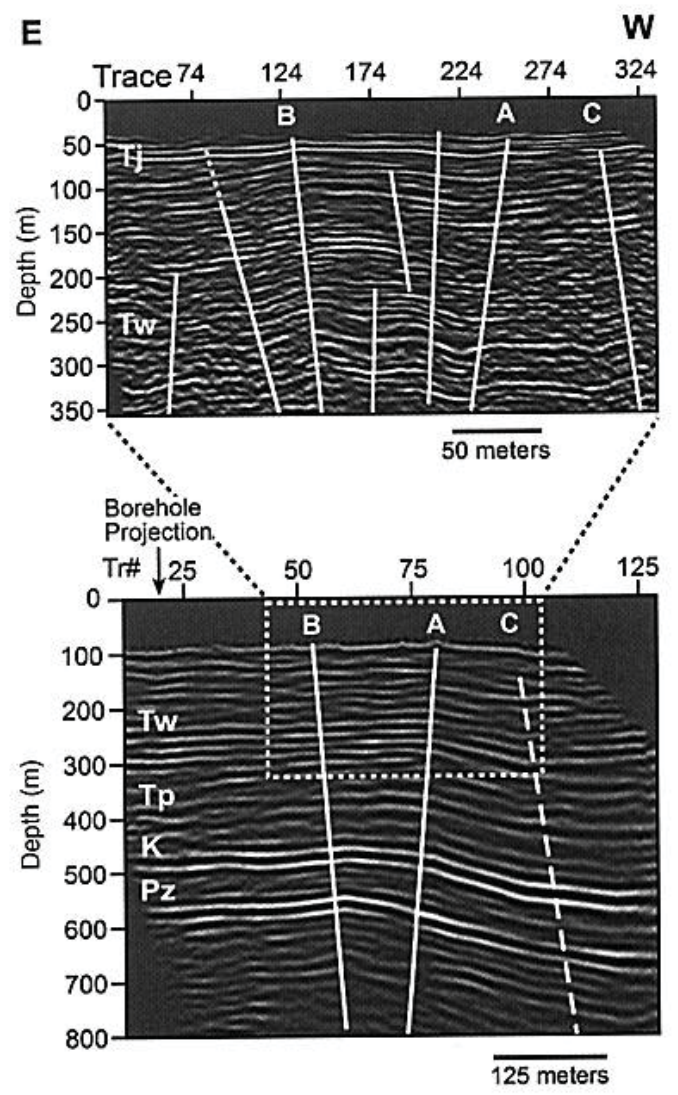

Figure 6. Uninterpreted stacked profiles of the east-west-oriented lines (a) UK 1 and (b) UK 1a. The profile locations are shown in Figure 3. (c) The spatial relationship between the interpreted UK 1 and $1 \mathrm{a}$. UK 1 was arrayed to target the deeper $\mathrm{K}$ and $\mathrm{Pz}$ stratigraphic horizons. UK 1a was collected coincident with part of UK 1 using a shorter array spacing to better image the shallow stratigraphy and structure within the zone defined by the white dashed rectangle. A pop-up structure, bounded by high-angle faults A and B, crosses the $\mathrm{Tj}$ and deforms the base of the Quaternary sediment. Another fault, $\mathrm{C}$, has a more pronounced expression in UK $1 \mathrm{a}$ than in UK 1.

\section{Line UK 3}

Line UK 3, a $900 \mathrm{~m}$ long north-south-oriented profile (Fig. 8), was collected $0.30 \mathrm{~km}$ northeast of CUSSO (Fig. 3). The survey targeted the deeper horizons; however, unlike lines UK 1 and 2, the top of the Porters Creek is the most prominent reflection observed on the UK 3 profile. Although visible, the typically strong $\mathrm{K}$ and $\mathrm{Pz}$ reflections are relatively weak and less coherent. We interpret near-vertical faults at traces 130 and 80 that bound a region of uplifted strata that exhibit antiformal folding. These faults are labeled $\mathrm{A}$ and $\mathrm{B}$, respectively. Both $\mathrm{A}$ and $\mathrm{B}$ faults cross the reflected tops of the $\mathrm{Pz}, \mathrm{K}$, and Porters Creek, as well as affect the overlying horizons, including the Wilcox and younger strata. The largest amount of vertical relief occurs across fault $\mathrm{A}$, which has 50 and $75 \mathrm{~m}$ of displacement on the $\mathrm{K}$ and $\mathrm{Pz}$ horizons, respectively. The Porters Creek also exhibits nearly $50 \mathrm{~m}$ of structural relief. The reflectors in the area bounded by faults A and B are uplifted and antiformally warped, comparable to, and interpreted to be, the northeast continuation of the flower structure on lines UK 1 and 2. Another evident and significant deformation consisting of two faults, labeled $\mathrm{C}$, is at trace 150, near the northern end of the line (Fig. 8).
Fault C displacement has a pronounced apparent southern downthrow of $\sim 50 \mathrm{~m}$ on the Tp horizon; however, weakened signal deeper in the record precludes a definitive estimate along the $\mathrm{K}$ and $\mathrm{Pz}$ horizons. This is the largest observed vertical offset for fault $\mathrm{C}$ at the site. We also interpret a fault at trace 30 near the southern end of the profile. It is near vertical with $\sim 20 \mathrm{~m}$ of displacement and projects just off the eastern ends of lines UK 1 and 2 using a strike equivalent to that defined by faults $\mathrm{A}$ and $\mathrm{B}$.

\section{Line M-21}

The north-south-oriented M-21 is located in the Mississippi River floodplain of eastern Missouri and the stacked profile shown in Figure 9. Both the northeast extension of the Axial fault and the projected northeast strike for the fault stands interpreted in the higher-resolution lines intersect M-21 south of the community of Wolf Island, Missouri (Fig. 2). The enlarged inset in Figure 9 shows the $6 \mathrm{~km} \mathrm{sec}-$ tion of the profile that is centered on the projected intersection and defines our area of interest. The two most prominent reflections are the $\mathrm{K}$ and $\mathrm{Pz}$, at approximately $350 \mathrm{~ms}$ and $450 \mathrm{~ms}$ two-way travel time (TWTT), respectively. These 

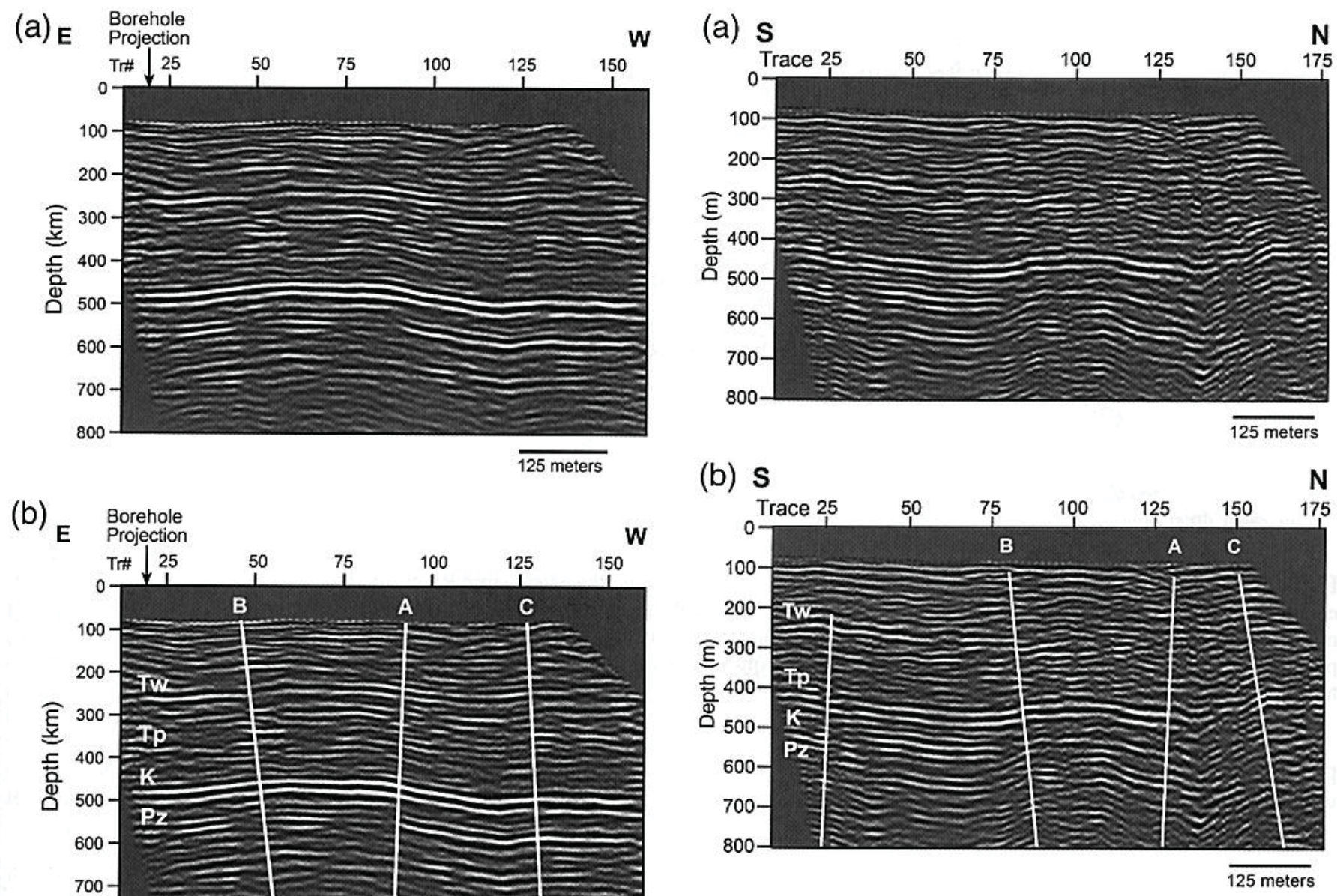

Figure 8. (a) Uninterpreted and (b) interpreted stacked profiles of the north-south-oriented UK 3. The line location is shown in Figure 3. A prominent pop-up structure is located between traces 80 and 130 (labeled $\mathrm{B}$ and $\mathrm{A}$, respectively) and extends above the $\mathrm{Pz}$ affecting all resolvable stratigraphic horizons. Fault $\mathrm{C}$, located at trace 150, exhibits more deformation here than in UK 1 and 2. Figure 3. A pop-up structure, bounded by high-angle faults $\mathrm{A}$ and $\mathrm{B}$, displace the $\mathrm{Pz}$ and $\mathrm{K}$ reflectors and deforms the resolved Tertiary sediments. Fault $\mathrm{C}$ near the end of the profile also disturbs Tertiary sediments.

reflection boundaries are similar to our high-resolution results and typical of those found in most seismic-reflection datasets in the embayment. Moreover, the stratigraphic correlations and data quality are consistent with those found in another nearby line from the same industry dataset (Baldwin et al., 2005). In the section of interest, we interpret three high-angle faults, labeled $\mathrm{A}, \mathrm{B}$, and $\mathrm{C}$, that disrupt the $\mathrm{K}$ and $\mathrm{Pz}$ horizons. Although the correlation of projected structure at long distances can be uncertain, the offset and style of the M-21 faults are very similar to those imaged in the highresolution data. Specifically, the interpreted faults A and B define a narrow ( $\sim 0.75 \mathrm{~km}$ wide), upward splaying asymmetric horst structure with uplifted antiformal reflectors. This is kinematically consistent with a northeast extension of the positive flower structure interpreted in lines UK 1, 2, and 3. The interpreted fault $\mathrm{C}$ in $\mathrm{M}-21$, located just north of $\mathrm{A}$ and $\mathrm{B}$, is also geometrically similar to the structure imaged in the high-resolution data. We further note that there is a broad and

significant structural rise immediately north of our interpreted transpression feature. This is likely associated with the Charleston uplift and/or beginning of the northwestern margin structures of the Reelfoot graben, suggesting that our projected transpression feature cojoins, crosses, or is truncated by these structures northeast of this location (Pryne et al., 2013). The M-21 data also show deep-seated deformation, truncating reflections perhaps as deep as $2 \mathrm{~s}$ TWTT. The overall low resolution in the dataset quality precludes us from making precise geometric measurements, thus our interpretations are pattern based. In addition, we do not attempt any interpretation for the less coherent data shallower than 350 ms TWTT.

\section{Discussion and Conclusions}

A goal for intraplate tectonics and its derivative seismichazard research in the NMSZ region is a better understanding of the parameters used for geodynamic modeling and seismic-hazard calculation, respectively. Pratt et al. (2012) made recent observations that the bend in the seismicity 


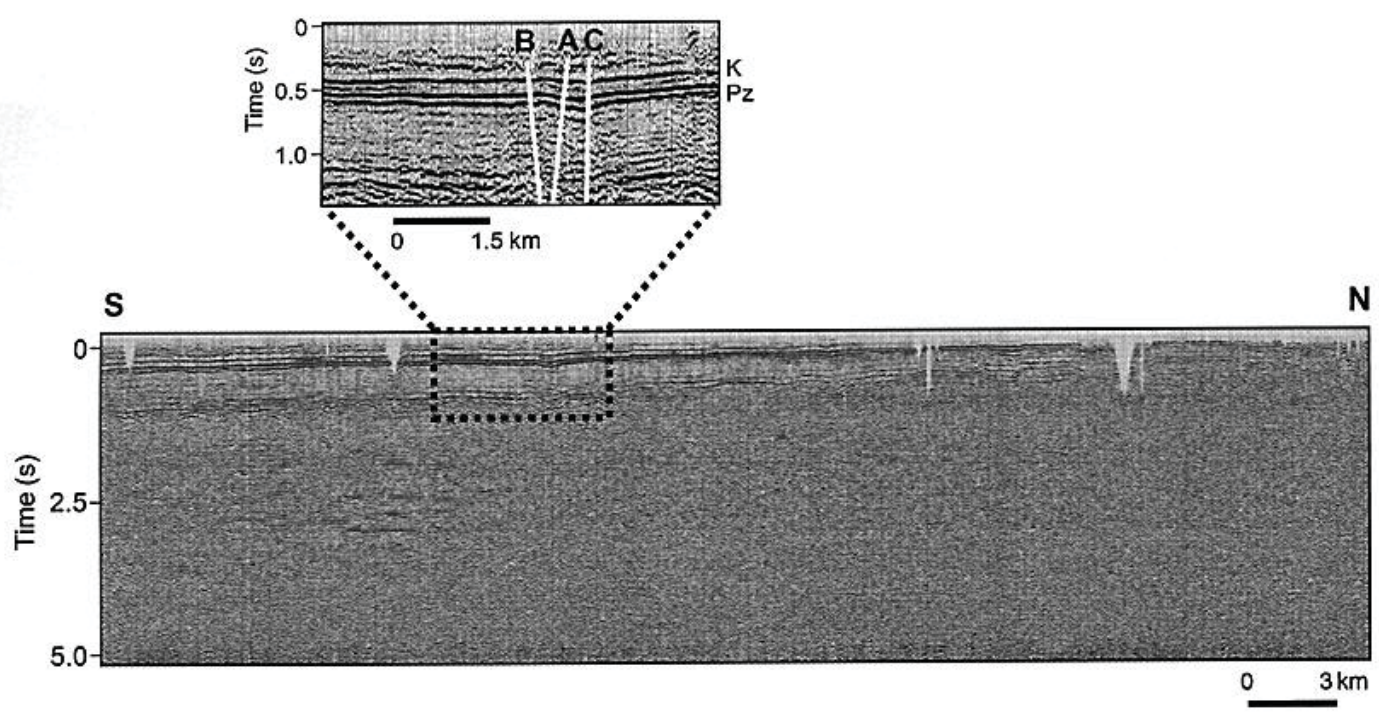

Figure 9. Dow Chemical Vibroseis line M-21 oriented north-south along the Mississippi River floodplain in southeastern Missouri. The enlarged $6 \mathrm{~km}$ area surrounds the point of structural intersection with the projected $\mathrm{N} 30^{\circ} \mathrm{E}$ strike defined by the high-resolution seismicreflection profiles. High-angle upward-splaying transpression faults similar to those identified in lines UK 1 to UK 3 are exhibited at the projected structural intersection. The data are much lower resolution but reveal uplifted and antiformally warped $\mathrm{Pz}$ and $\mathrm{K}$ reflections similar to those imaged in the higher resolution data.

pattern at the northeast-oriented Axial fault's intersection with the central stepover thrust results from right-lateral displacement along the Reelfoot fault, and that the lateral displacements between the Reelfoot fault and its surface expression, Reelfoot scarp, are unbalanced. These observations formulate the hypothesis that the Axial shear zone continues to the northeast across the stepover to accommodate the differential strain (Fig. 2). We acquired a series of seismic-reflection profiles in an area $12 \mathrm{~km}$ northeast of the central stepover and along the western margin of the Pratt et al. (2012) shear-zone projection (Fig. 3). These data exhibit a set of steeply dipping faults that have uplifted and arched post-Paleozoic sediments in a manner consistent with positive flower structures found in dextral strike-slip displacement, and similar to transpression features interpreted in other regional seismic profiles (e.g., Van Arsdale et al., 1995; Odum et al., 1998; among others). Our interpreted fault zone strikes approximately $\mathrm{N} 30^{\circ} \mathrm{E}$ and was correlated and traced $1.4 \mathrm{~km}$ between the reflection surveys. These data are too closely spaced for a meaningful regional scaled inference. Consequently, we projected the structure northeast along strike approximately $22 \mathrm{~km}$ to its intersection with a lower-resolution industry reflection profile as an initial evaluation of the areal extent (Fig. 10). The reflection image at the site of intersection revealed a discrete set of upward-splaying high-angle faults that bounded a subsurface area with an uplifted and arched $\mathrm{K}$ reflection. This $\sim 750 \mathrm{~m}$ wide zone has a comparable style to the $\sim 200 \mathrm{~m}$ wide structural feature imaged on the high-resolution seismic-reflection profiles acquired at the CUSSO site. The increase in structural width is perhaps influenced by the broader nearby structures seen in the profile; however, it may be an artifact of the horizontal resolution, a changing strike, and/or an incom- plete imaging of a broader structure at the CUSSO site. Whereas lines 1-3 were too closely grouped to make an indisputable regional structural interpretation, we also recognize that their significant separation from the industry data can also make a correlative interpretation equivocal. Having said that, the current dataset is kinematically indicative of a significant regional transpression structure. The high-resolution data also show that structural relief extends above $\mathrm{Pz}$ bedrock, crossing $\mathrm{K}, \mathrm{T}$, and the base of the Quaternary sediments. We note the Mississippi River floodplain at the CUSSO site is marked by a subtle topographic high $(\sim 3 \mathrm{~m})$ that may be structurally influenced, but this relationship remains speculative and requires further higher resolution study (i.e., ground penetrating radar, shallow drilling, trenching, etc.). The $\mathrm{Pz}$ and $\mathrm{K}$ horizons, however, show as much as 75 and $50 \mathrm{~m}$ of structural relief, respectively, with the middle Eocene and basal Quaternary displaced 25 and $15 \mathrm{~m}$, respectively. The fault orientation and deformation style at the CUSSO site and the positive regional correlation with the industry data indicate a northeast-oriented transpression structure orthogonal to the Reelfoot stepover and along the central embayment axis. The structure is too far inboard to have an association with northeast-oriented Reelfoot rift margins but is coincident with the projection of the Axial fault. Therefore, we interpret these newly discovered faults to be part of Pratt et al. (2012) hypothesized northeastoriented shear zone extension that crosses the NMSZ leftstepover thrust. Our interpretation extends the shear zone a minimum $34 \mathrm{~km}$. In addition, our interpretation is consistent with the interpretation of Odum et al. (1998) of northeast-oriented partitioning strike-slip faults in the hanging wall of the central stepover Reelfoot thrust and potentially part of their interpreted New Markham fault that was discovered 


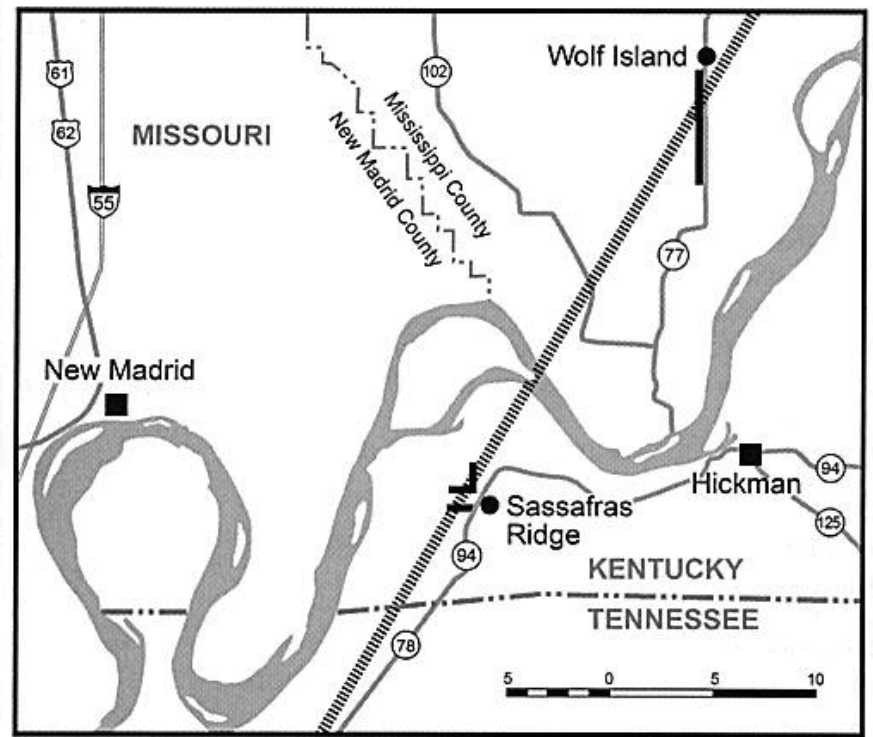

Figure 10. Relationship of the transpressional feature (short dashed line) interpreted between the high-resolution lines UK 1 to UK 3 and the lower-resolution M-21. Additional study is required to better validate the spatial and temporal relationships; however, these data provide the first corroborative physical evidence for a significant transpression structure that crosses the NMSZ's leftstepover arm, accommodating the unbalanced strain between the Reelfoot fault and scarp.

just north of the stepover with an anomalous north-oriented strike. The modeling and analog comparisons of Pratt (2012) for the New Madrid stepover structure also resulted in a kinematic framework that included a major northeast-oriented shear zone, although it was spatially located in Missouri, northwest of our site. Consequently, our interpretation reveals initial physical evidence consistent with recent modeland observation-based hypotheses regarding strain accommodation. In addition, it provides well-constrained location and geometry for Quaternary-active faults, thus providing more definitive spatial and eventual temporal parameters that can improve central United States intraplate tectonics and seismic-hazard models. More comprehensive geophysical and geologic study is required to evaluate the spatial and temporal limits of these structures as well as the range of their implications.

\section{Data and Resources}

All data presented in this study are part of the University of Kentucky seismic-hazard database. The high-resolution seismic-reflection data were collected and processed by faculty and students at the University of Kentucky. Unprocessed and processed versions are available from the authors. The seismic signal processing was performed with VISTA13 by Schlumberger-GEDCO. Topographic information used for construction of Figure 3 was constructed from maps downloaded from the Kentucky Geological Survey using http:// kgs.uky.edu/kgsweb/main.asp (last accessed May 2014).

\section{Acknowledgments}

This work was financially supported by U.S. Geological Survey-National Earthquake Hazards Reduction Program (NEHRP; Awards 08HQGR0094 and G11AP20156), Department of Energy/Kentucky Research Consortium for Energy and Environment (Award DE-FG05-03OR23032), and the Kentucky Geological Survey (KGS). The authors appreciate Roy Van Arsdale's helpful initial review. We also appreciate Jack Odum and one anonymous reviewer, as well as Associate Editor Delphine Fitzenz, for their comments that significantly improved the manuscript. Daniel Hunter, Anthony Paschall, David Butler, Carrington Wright, and Clayton Brengman provided essential data acquisition assistance. We also thank Collie Rulo (KGS) for her graphic arts assistance.

\section{References}

Baldwin, J. N., J. B. Harris, R. B. Van Arsdale, R. Givler, K. I. Kelson, J. L. Sexton, and M. Lake (2005). Constraints on the location of the Late Quaternary Reelfoot and New Madrid north faults in the northern New Madrid seismic zone, central United States, Seismol. Res. Lett. 76, 772-789.

Calais, E., and S. Stein (2009). Time-variable deformation in the New Madrid seismic zone, Science 323, 1442.

Calais, E., A. Freed, R. Van Arsdale, and S. Stein (2010). Triggering of New Madrid seismicity by late-Pleistocene erosion, Nature 466, 608-610.

Calais, E., G. Mattioli, C. DeMets, J.-M. Nocquet, S. Stein, A. Newman, and P. Rydelek (2005). Tectonic strain in plate interiors? Nature 438, E9-E10.

Chiu, J. M., A. C. Johnston, and Y. T. Yang (1992). Imaging the active faults of the central New Madrid seismic zone using PANDA array data, Seismol. Res. Lett. 63, 375-393.

Cox, R. T., and R. B. Van Arsdale (2002). The Mississippi embayment, North America: A first order continental structure generated by the Cretaceous superplume mantle event, J. Geodyn. 34, 163-176.

Cox, R. T., R. B. Van Arsdale, J. B. Harris, S. L. Forman, W. Beard, and J. Galuzzi (2000). Late Quaternary faulting in the southern Mississippi embayment and implications for regional neotectonics, Bull. Geol. Soc. Am. 112, 1724-1735.

Csontos, R., and R. Van Arsdale (2008). New Madrid seismic zone fault geometry, Geosphere 4, 802-813.

Csontos, R., R. Van Arsdale, R. Cox, and B. Waldron (2008). The Reelfoot Rift and its impact on Quaternary deformation in the central Mississippi River valley, Geosphere 4, 145-158.

Howe, J. R. (1985). Tectonics, sedimentation, and hydrocarbon potential of the Reelfoot aulacogen, Master's Thesis, University of Oklahoma, Norman, Oklahoma, 109 pp.

Hunter, D. L. (2011). Defining the geologic site model for the central United States seismic observatory, Master's Thesis, University of Kentucky, Lexington, Kentucky, 68 pp.

Johnston, A. C., and E. S. Schweig (1996). The enigma of the New Madrid earthquakes of 1811-1812, Ann. Rev. Earth Planet. Sci. 24, 339-384.

Newman, A., S. Stein, J. Weber, J. Engeln, A. Mao, and T. Dixon (1999). Slow deformation and lower seismic hazard at the New Madrid seismic zone, Science 284, 619-621.

Odum, J. K., W. Stephenson, K. Shedlock, and T. Pratt (1998). Nearsurface structural model for deformation associated with the February 7, 1812, New Madrid, Missouri, earthquake, Bull. Geol. Soc. Am. 110, $149-162$.

Odum, J. K., W. J. Stephenson, and R. A. Williams (2010). Multi-source, high-resolution seismic-reflection imaging of Meeman-Shelby fault and possible tectonic model for a Joiner Ridge-Manila High structure in the upper Mississippi embayment region, Seismol. Res. Lett. 81, $647-660$.

Pratt, T. L. (1994). How old is the New Madrid seismic zone? Seismol. Res. Lett. 65, 172-179.

Pratt, T. L. (2012). Kinematics of the New Madrid seismic zone, central U.S., based on stepover models, Geology 40, 371-374. 
Pratt, T. L., R. A. Williams, J. K. Odum, and W. J. Stephenson (2012). Origin of the Blytheville Arch, and long-term displacement on the New Madrid seismic zone, central United States, in Recent Advances in North American Paleoseismology and Neotectonics East of the Rockies, R. T. Cox, M. P. Tuttle, O. S. Boyd, and J. Locat (Editors), Geol. Soc. Am. Special Paper 493, 1-15, doi: 10.1130/ 2012.2493(01).

Pryne, D., R. Van Arsdale, R. Csontos, and E. Woolery (2013). Northeastern extension of the New Madrid north fault, New Madrid seismic zone, central United States, Bull. Seismol. Soc. Am. 103, 2277-2294.

Pujol, J., A. Johnston, J. Chiu, and Y. Yung-tun (1997). Refinement of thrust faulting models for the central New Madrid seismic zone, Eng. Geol. 46, 281-298.

Schweig, E., and M. A. Ellis (1994). Reconciling short recurrence intervals with minor deformation in the New Madrid seismic zone, Science 264, 1308-1311.

Smalley, R., Jr., M. A. Ellis, J. Paul, and R. B. Van Arsdale (2005). Space geodetic evidence for rapid strain rates in the New Madrid seismic zone of central USA, Nature 435, 1088-1090.

Stein, S., and A. Newman (2004). Characteristic and uncharacteristic earthquakes as possible artifacts: Applications to the New Madrid and Wabash seismic zones, Seismol. Res. Lett. 75, 172-187.
Tuttle, M. P., E. S. Schweig, J. D. Sims, R. H. Lafferty, L. W. Wolf, and M. L. Haynes (2002). The earthquake potential of the New Madrid seismic zone, Bull. Seismol. Soc. Am. 92, 2080-2089.

Van Arsdale, R. B. (2000). Displacement history and slip rate on the Reelfoot fault of the New Madrid seismic zone, Eng. Geol. 55, 219-226.

Van Arsdale, R. B., R. A. Williams, E. S. Schweig, K. M. Shedlock, J. K. Odum, and K. W. King (1995). The origin of Crowley's Ridge, northeastern Arkansas: Erosional remnant or tectonic uplift? Bull. Seismol. Soc. Am. 85, 963-986.

Wheeler, R. L. (1997). Boundary separating the seismically active Reelfoot rift from the sparsely seismic Rough Creek graben, Seismol. Res. Lett. 68, 586-598.

Department of Earth and Environmental Sciences

University of Kentucky

101 Slone Research Building

Lexington, Kentucky 40506-0053

Manuscript received 15 March 2014;

Published Online 9 September 2014 